\title{
Validity and Reliability of a Korean Version of Nursing Student Perceptions of Dishonesty Scale
}

\author{
Woo, Hee-Yeong ${ }^{1) \oplus} \cdot$ Han, Jeongwon ${ }^{2)}$
}

1) Assistant Professor, School of Nursing, Sahmyook Health University, Seoul, 2) Assistant Professor, College of Nursing Science, Kyung Hee University, Seoul, Korea

\begin{abstract}
Purpose: This study was conducted to evaluate the validity and reliability of the Korean version of Nursing Student Perceptions of Dishonesty Scale (NSPDS). Methods: The English NSPDS was translated into Korean after going through a translation and reverse translation process. Data for this study were collected from 433 student nurses from 8 universities in Korea, who had clinical practice experience. The final data were evaluated using SPSS 20.0 and AMOS 22.0 for exploratory and confirmatory factor analysis. Reliability was tested using Cronbach's $\alpha$ and test-retest reliability. Results: The exploratory factor analysis showed that 15 items were deleted and 9 subscales were changed into 8 subscales, and the initial 67 items were reduced to 52 items. Confirmatory factor analysis was conducted with 8 subscales and 52 items. The standardized regression coefficients of all the items were statistically significant and between .66 and .93 . Convergent validity confirmed that the critical ratio was greater than .85 , and the average variance extracted was greater than .53 . The criterion-related validity confirmed a negative correlation between student nurses' ethical value and the Korean version of NSPDS. Reliability was confirmed with a Cronbach's $\alpha$ of .80 .95. The test-retest confirmed that the correlation coefficient showed significant positive correlations between .68 and .76 in the subscales. Conclusion: The findings of this study suggest that the Korean version of NSPDS is an appropriate and reliable tool for identifying dishonesty perceptions among Korean student nurses.
\end{abstract}

Key Words: Nursing; Perception; Students; Reproducibility of results

Received Jan 16, 2020 Revised Mar 26, 2020 Accepted May 6, 2020

Corresponding author: Han, Jeong-Won https://orcid.org/0000-0002-4893-8327

College of Nursing Science, Kyung Hee University

26 Kyunghee-daero, Dongdaemun-gu, Seoul 02453, Korea

Tel: +82-2-961-2123, Fax: +82-2-961-2123, E-mail: hjw0721@naver.com 


\section{INTRODUCTION}

Academic dishonesty refers to various actions on the part of students that go against the expected norms of a school, university, or other learning institution [1]. Academic dishonesty is associated with a variety of factors, but ethicists explain that a student's ethical values can also cause or motivate academic dishonesty [2]. The Ethical Concepts Applied to Nursing serve as a guideline for human relations, a standard for judgment in certain situations, and emphasize ethical, honest, and responsible behaviors that define a nurse [3]. This means that a nurse's dishonest and unethical behavior as a health-care provider can have negative repercussions on a patient's life [4]. Because of this, nursing educators and students alike need to consider the serious consequences of dishonest behavior [5].

Recently, many researchers have reported dishonest behavior as a frequently occurring problem among student nurses throughout the world [6]. In a previous study, more than $50.0 \%$ of student nurses tried various dishonest behaviors. The type of dishonest behavior student nurses can commit in clinical settings include the following: not reporting incidents or errors related to the patient during clinical practice; reporting or documenting nursing care that was not performed; documenting drugs that were not administered as documented; documenting different responses to treatment or drugs; documenting or reporting vital signs that were not measured or could not be accurately remembered; nursing without appropriate knowledge or guidance; not following the aseptic technique or leaving medical supplies contaminated without changing them; discussing patient's information in public or with others; using uncertain data to carry out a case presentation or falsely modifying data; and taking hospital supplies or medications for personal use [5]. In the classroom, student nurses have also been reported to try various dishonest behaviors such as writing cheat sheets on the arm; going to the restroom during a test to check notes with already written answers; and taking pictures of a friend's assignment to copy, as well as some cases of plagiarism [7].

Dishonest behaviors of student nurses in the classroom or clinical setting may also depend on both how they perceive academic dishonesty as an unethical behavior and how strongly they disapprove of academic dishonesty [8]. Therefore, nurse educators are responsible for identifying the types and causes of student nurses' dishonest behaviors and preventing them, because nurses are the healthcare providers of the future and their behaviors will impact their patients' lives [5]. In addition, based on the theo- ry of moral reasoning and social cognitive theory, even if dishonest behaviors of student nurses may occur based on individual thoughts and motives, they can still have negative effects on others if misinterpreted $[9,10]$. It is consequently essential that nurse educators measure the degree of students nurses' perception of dishonest behaviors to prevent student dishonesty.

Currently available tools to measure dishonesty among student nurses' focus mostly on unethical and immoral behaviors [11-13]. In particular, a tool used to measure the unethical attitude of student nurses in a previous domestic study was developed to measure medical students' awareness of academic ethics. However, some items of this study are not suitable for student nurses [14]. On the other hand, the NSPDS was developed for student nurses in the United States to measure dishonesty among nursing students [15]. The NSPDS consists of items measuring perceptions of dishonest behaviors that can occur in the classroom and clinical settings [16]. Subsequently, these results can be used as baseline data for developing educational programs to correct the perception and behaviors of Korean student nurses in relation to dishonesty. In addition, NSPDS factors can help nurse educators apply individual interventions by identifying academic dishonesty factors that a student may perceive to be relatively low. Moreover, the NSPDS focuses on the student's behavior at school rather than the student's general honesty, ethics, or morality. Therefore, this study was conducted to identify the validity and reliability of the Korean version of NSPDS, to assess the perception of student nurses regarding dishonesty, and to provide baseline data for the nursing education process to instill work ethics in nurses.

\section{METHODS}

\section{Study Design}

This is a methodological study to provide baseline data to dishonesty of student nurses in Korea by translating NSPDS [15] into Korean.

\section{Setting and Sample}

This study was conducted with sophomore, junior, and senior student nurses from 8 universities in 5 regions of Korea (Seoul, Gyeonggi-do, Gyeongsang-do, Jeolla-do, and Gangwon-do) who had clinical practice experience. A total of 440 students who understood the study purpose and who voluntarily signed informed consent were selected. The number of subjects was calculated based on the ration- 
ale of Hinkin [17], who suggested that at least 150 200 subjects are appropriate for exploratory factor analysis, and a rationale of Anderson and Gerbing [18], who suggested a minimum of 150 subjects for confirmatory factor analysis. Therefore, the number of participants sufficient for the exploratory and confirmatory factor analyses was set at 400 , and considering a dropout rate of approximately $10 \%$, a total of 440 students received survey questionnaires. The final data were randomly divided into equal parts for exploratory and confirmatory factor analyses. In addition, the minimum sample size for test-retest was 50 [19], and the sample size for this study was set to 100 to increase accuracy. Furthermore, a total of 100 participants who consented to the second survey during the first survey, received survey questionnaires for the test-retest. A total of 433 survey questionnaires out of 440 were collected and used for the final analysis.

\section{Measurements}

\section{1) Nursing students' perceptions of dishonesty}

This study used the NSPDS [15] to measure nursing student nurses' perceptions of dishonesty. The NSPDS is categorized into two areas: classroom and clinical settings. The classroom category had a total of 40 items from $6 \mathrm{sub}-$ scales: cheating (actions given or taken in an attempt to do well in tests or assignments without doing the actual work), 13 items; assistance (to improve one's work with the help of others), 9 items; cutting corners (actions taken to lessen the amount of work to be done), 7 items; not my problem (being aware of the academic dishonesty of others but not reporting it), 4 items; sabotage (negatively impacting another's work), 4 items; and test file (maintaining or using former tests or test question banks), 3 items. The clinical settings category had a total of 27 items from 3 subscales: perjury (creating or providing false or inaccurate information, to make up or lie), 13 items; noncompliance (failing to follow set guidelines, rules, or stated expectations), 11 items; and stealing (to take without permission or right), 3 items. Each item has a rating of 1 to 4 (1: strongly disagree - 4: strongly agree, score range: $67 \sim 268)$, the higher the score, the higher the perception of student nurses' dishonesty. The reliability of the tool during development was Cronbach's $\alpha$ of .62 .96.

\section{2) Nursing students' ethical values}

Nursing students' ethical value was assessed using a tool developed by Jeong [20] and was revised by Kim [21] for the use of student nurses. These students' ethical value consisted of 38 items with 4 subscales and each item used a 5-point Likert scale (1: strongly disagree - 5: strongly agree, score range: 38 190), the higher the score, the higher the nursing students' ethical value. The reliability of the tool during development was Cronbach's $\alpha$.68 .87[20], the reliability in Kim's study was Cronbach's $\alpha$.56 .68[21], and the reliability in this study was Cronbach's $\alpha$.79 .81.

\section{3) Translation and cultural adaptation processes}

Using the translation tool and application guidelines recommended by the World Health Organization (WHO) [22] for the use of the English tool in other languages and cultures, this study completed the preliminary items after a primary translation, expert panel review, a reverse translation, and a cognitive interview processes. Before starting the primary translation, the study team obtained approval for the Korean translation and its use from the tool developer. It was recommended that the primary translation be conducted by health experts familiar with the terminology of the field as well as the English culture, and whose native language was the language into which the document would be translated [22]. This study requested a primary translation from two doctors of nursing who are fluent in English and with sufficient experience in nursing terminology. These two professionals conducted the primary translation independently. In addition, primary translation sentences were agreed on to avoid a word-for-word translation and to convey the overall meaning of the sentences. The expert panel consisted of an expert bilingual translator, two nursing professors who were fluent in both languages, and the two doctors of nursing in charge of the primary translation. The panel reviewed the primary translation by comparing the translated and original sentences in English. Reverse translation was then requested from a U.S. citizen whose native language is English and who was also fluent in Korean. Although the reverse translated sentences were not exactly matched to the original tool, it was confirmed that there were no changes in meaning and preliminary items were completed. Content validity was confirmed by two nursing doctors, two nursing professors, and one doctoral student in nursing. To ensure homogeneity of word meaning and review the response process, a cognitive validity assessment was conducted on 10 nursing students.

\section{4) Data collection}

Prior to the initiation of all study procedures and to protect the student nurses and for all ethical considerations, this study obtained the approval of S University IRB (**IRB 1810-01). The data collection period was from October 25, 2018 to November 30, 2018. The nursing de- 
partments of nursing of 8 universities located in 5 regions (Seoul, Gyeonggi-do, Gyeongsang-do, Jeolla-do, and Gangwon-do) in Korea were selected using a convenient sampling method. Study purposes and methods were first explained to the department chair via phone, and the study's content, methods, and survey questionnaires were then sent to the department chair via email for further review. Data were collected using the survey questionnaires with the approval and support of the department chair. Student nurses from 2 universities were selected for test-retest. Notice of the second survey was given in advance, and the re-examination date and contents were explained. Once the students agreed to participate in the reexamination, they were told to use a unique identification number in the survey questionnaire. The second survey was conducted 2 weeks after the first survey.

\section{5) Data analysis}

Data collected were analyzed using IBMStatistics AMOS 22.0 and SPSS Statistics 20.0. In order to investigate the general characteristics of the students, frequency, percentage, mean, and standard deviation were used. In the case of exploratory factor analysis, we examined the KaiserMeyer-Olkin (KMO) value of sampling adequacy. KMO values of .70 [17]. and above supported the use of factor analysis on the data. In addition, we examined Bartlett's test of sphericity to determine if the correlation matrix of the items was an identity matrix, meaning that there were no relationships between the items. To identify the most interpretable structure, we analyzed the principle component analysis. Rotations were assessed using Varimax. The number of factors was extracted based on eigenvalues of 1.0 or higher, and items were selected based on factor loadings of .40 or higher. In the confirmatory factor analysis, the model fit index was confirmed based on Normed $x^{2}\left(x^{2} / \mathrm{df}\right)$, Tucker-Lewis index (TLI; reference value: $\left.\geq .90\right)$, comparative fit index (CFI; reference value: $\geq .90)$, and root mean square error of approximation (RMSEA; reference value: $\leq .05)$, and standardized root mean residual (SRMR; reference value: $\leq .05)$. Moreover, the convergent validity of the factor construct was checked based on the following criteria: standardized regression coefficients of observed variables $\geq .50$, construct reliability $(\mathrm{CR}) \geq .70$, and average variance extracted (AVE) $\geq .50[23]$. The discriminant validity of the factors estimated by CFA was verified based on the criteria that inter-factor correlation coefficients should be $\leq .80$ and the AVE of latent variables should be greater than the square of the correlation coefficients of the latent variables. To test the criterion validity of the Korean NSPDS, a gold standard scale with pro- ven validity and reliability should be used. However, because there are very few instruments designed to measure dishonesty in nursing student nurses and almost none have proven validity and reliability, we compared our findings to a previous study [21] on student nurses' ethical values. For a criterion-related validity analysis, a Pearson's correlation coefficient between the Korean version of the NSPDS and the nursing students' ethical values was calculated, and the reliability test calculated Cronbach's $\alpha$ correlation coefficient of internal consistency. The reliability of the test-retest was calculated as a Pearson correlation coefficient. Finally, an item analysis on final items was conducted to identify the mean, standard deviation, standard error, skewness, and kurtosis.

\section{RESULTS}

\section{Participants' Demographic Characteristics}

Most of the students were female: 386 female (89.1\%) and 47 male (10.9\%). The mean age of the students was 23.1 years, and 92 were sophomores (21.2\%), 170 were junior students (39.3\%), and 171 were senior students (39.5\%). Ninety-two students (21.2\%) had experienced a leave of absence or transfer. On satisfaction with their grade-point average, 32 (7.4\%) were "very satisfied", 113 (26.1\%) were "satisfied", $166(38.3 \%)$ chose "neutral”, 103 (23.8\%) selected "unsatisfactory", and 19 (4.4\%) selected "very unsatisfactory". The most common reason for choosing nursing as a career was "high employment rate" in 242 students (55.9\%) (Table 1$)$.

\section{Content Validity}

This study carried out a strict and systematic translation process of the original tool in English using the tool translation and application guidelines of the WHO [22] in order to ensure content validity. Two nursing doctors, two nursing professors, and one doctoral student in nursing, also confirmed content validity. After reviewing the appropriateness of the items and adequacy, and representativeness of those in the subscales, all the subscales showed "valid" or "very valid" and all the items showed a CVI ranging between .80 and 1.00. The item CVI estimates that appropriate content validity is obtained at .80 or higher [24]. Items with terminology not suitable for the Korean situation, awkward expressions, and phrases were also revised. An example of a text that had to be revised is the following: "A student eats graham crackers from the patient pantry." Graham crackers are not part of our country's food 
Table 1. General Characteristics of the Student Nurses $(N=433)$

\begin{tabular}{llr}
\hline Variables & Categories & $\begin{array}{r}\mathrm{n}(\%) \text { or } \\
\mathrm{M} \pm \mathrm{SD}\end{array}$ \\
\hline Gender & Male & $47(10.9)$ \\
& Female & $386(89.1)$ \\
& & $23.1 \pm 3.69$ \\
Age (year) & $\leq 23$ & $256(59.1)$ \\
& $>23$ & $177(40.9)$ \\
Grader & Sophomore & $92(21.2)$ \\
& Junior & $170(39.3)$ \\
& Senior & $171(39.5)$ \\
Experience on leave of & Yes & $92(21.2)$ \\
absence or transfer & No & $341(78.8)$ \\
\hline Satisfaction for GPA & Very satisfied & $32(7.4)$ \\
& Satisfied & $113(26.1)$ \\
& Neutral & $166(38.3)$ \\
& Unsatisfactory & $103(23.8)$ \\
& Very unsatisfactory & $19(4.4)$ \\
\hline Reason for choosing & High employment rate & $242(55.9)$ \\
nursing & Based on score & $159(36.7)$ \\
& Based on aptitude & $32(7.4)$ \\
\hline
\end{tabular}

$\mathrm{GPA}=$ Grade point average.

culture, and we transformed "graham crackers" into "food". In the case of the sentence, "A student studies exams from a test file," the words "test file" were changed to jokbo to increase the readability of study for the participants. The investigators applied the actual tools and conducted a cognitive validity assessment to ensure content validity for 10 nursing students. The students took about 20 minutes for the survey, and we confirmed that the students had no difficulty reading and completing the survey.

\section{Construct Validity}

Confirmatory factor analysis was conducted with a 217 data set in order to confirm whether the construct validity of the Korean version tool could be tested with 67 items and 9 component factors from the original tool. Although the standardized regression coefficients of all items with bootstrapping were more than .50 , the fit index of the model was low, and it was suggested that one observation variable should be set as a causal relationship for multiple factors. Thus, a new model estimate was required for an exploratory factor analysis of the total 67 items with a different 216 data set. The Kaiser-Meyer-Olkin (KMO) value to confirm the adequacy of the factor analysis sample was .88 , which was greater than the reference value of .70 [17]. Bartlett's sphericity test results showed that the approximation $x^{2}$ value was $10,114.22(\mathrm{df}=1,326, p<.001)$, which confirmed the use of factor analysis as appropriate. Factor analysis of the total of 67 items extracted 8 factors with more than 1.0 of eigenvalues (eigenvalues of factors: factor $1=17.60$, factor $2=4.65$, factor $3=4.28$, factor $4=2.42$, factor $5=1.86$, factor $6=1.67$, factor $7=1.37$, factor $8=1.04$ ) . A communality below 0.3 indicated that the variable may have little in common with any of the other variables and was dropped from the analysis [25]. Fifteen items with less than .30 of communality were deleted ("When asked to witness a medication waste, the student signs off but did not watch to ensure if the drug was wasted," "A student documents that the nurse was notified when, in reality, the nurse was not notified," "A student reports being sick when s/ he is not able to alter the time of an exam," "A student gives a patient inaccurate information about her/ his status," "While in a clinical setting, a student has a headache and takes a patient's Tylenol," "A student memorizes test questions to look up after the exam," "A student eats graham crackers from the patient pantry," "A student breaks sterility and does not reestablish it," "A student does not wash his hands between patients," "A student uses a classmate's notes to study for an exam," "A student uses the writing center to have a paper edited for writing style and organization," "A student accepts a cash gift from a patient," "A student studies with a classmate for an exam," "A student takes and uses TEDs/surgical stockings from the supply room for personal use," and "A student makes up an entire patient assessment and documents it as facts.”). The communality of all the other items was above .50. Regression coefficients of the pattern matrix of all items met the criteria, greater than .40 [26]. Based on the exploratory factor analysis, 3 items from stealing in the clinical settings category were deleted. Therefore, the initial 67 items (9 subscales) were reduced to 52 items (8 subscales) (Supplement 1). The cumulative variance ratio of factors was $69.2 \%$ (variance ratio of factors: factor $1=$ 17.61 , factor $2=10.67$, factor $3=10.45$, factor $4=8.37$, factor $5=6.09$, factor $6=5.89$, factor $7=5.74$, factor $8=4.38$ ).

A confirmatory factor analysis was conducted with 8 factors and 52 items with the following processes. Fitness of the model evaluation showed that $x^{2}$ of $3735.09(\mathrm{df}=$ $1261, p<.001$ ), normed $x^{2}$ of 2.96 , SRMR of .05, TLI of .90, CFI of .91, and RMSEA of .06 (low $=.05$, high $=.07$ ), which revealed that fitness met a standard. The validity of the component factors was confirmed using convergent and discrimination validity with the final model. Standardized regression coefficients of all items were statistically significant and between .66 and .93 . Convergent validity was confirmed based on the following: CR was greater than .85 , AVE was greater than .53, and the Pearson correlation 
Table 2. The Result of Confirmatory on Korean NSPDS

\begin{tabular}{|c|c|c|c|c|c|c|c|c|}
\hline Factors & Item no & B & $\beta$ & SE & Critical ratio & $p$ & CR & AVE \\
\hline F1 & $\begin{array}{r}1 \\
2 \\
3 \\
4 \\
5 \\
6 \\
7 \\
8 \\
9 \\
10 \\
11 \\
12 \\
13\end{array}$ & $\begin{array}{l}1.00 \\
1.01 \\
1.54 \\
0.83 \\
1.37 \\
0.79 \\
1.44 \\
1.11 \\
1.71 \\
1.39 \\
1.45 \\
1.48 \\
0.83\end{array}$ & $\begin{array}{l}.70 \\
.76 \\
.87 \\
.76 \\
.86 \\
.74 \\
.76 \\
.78 \\
.71 \\
.78 \\
.87 \\
.79 \\
.73\end{array}$ & $\begin{array}{l}- \\
.03 \\
.08 \\
.05 \\
.08 \\
.05 \\
.09 \\
.07 \\
.12 \\
.09 \\
.08 \\
.09 \\
.05\end{array}$ & $\begin{array}{c}- \\
31.19 \\
17.35 \\
15.25 \\
17.12 \\
14.72 \\
15.22 \\
15.77 \\
14.16 \\
15.60 \\
17.35 \\
15.88 \\
14.63\end{array}$ & $\begin{array}{l}<.001 \\
<.001 \\
<.001 \\
<.001 \\
<.001 \\
<.001 \\
<.001 \\
<.001 \\
<.001 \\
<.001 \\
<.001 \\
<.001 \\
<.001\end{array}$ & .98 & .81 \\
\hline F2 & $\begin{array}{l}14 \\
15 \\
16 \\
17 \\
18\end{array}$ & $\begin{array}{l}1.00 \\
1.09 \\
1.21 \\
1.01 \\
1.15\end{array}$ & $\begin{array}{l}.68 \\
.70 \\
.79 \\
.70 \\
.75\end{array}$ & $\begin{array}{c}- \\
.08 \\
.08 \\
.09 \\
.08\end{array}$ & $\begin{array}{c}- \\
12.47 \\
13.72 \\
10.93 \\
13.23\end{array}$ & $\begin{array}{l}<.001 \\
<.001 \\
<.001 \\
<.001 \\
<.001\end{array}$ & .85 & .53 \\
\hline F3 & $\begin{array}{l}19 \\
20 \\
21 \\
22 \\
23 \\
24 \\
25\end{array}$ & $\begin{array}{l}1.00 \\
1.06 \\
0.95 \\
0.94 \\
0.91 \\
1.03 \\
1.13\end{array}$ & $\begin{array}{l}.71 \\
.73 \\
.68 \\
.66 \\
.66 \\
.76 \\
.77\end{array}$ & $\begin{array}{l}- \\
.07 \\
.07 \\
.07 \\
.07 \\
.07 \\
.07\end{array}$ & $\begin{array}{c}- \\
13.89 \\
12.98 \\
12.56 \\
12.56 \\
14.45 \\
14.67\end{array}$ & $\begin{array}{l}<.001 \\
<.001 \\
<.001 \\
<.001 \\
<.001 \\
<.001 \\
<.001\end{array}$ & .87 & .53 \\
\hline F4 & $\begin{array}{l}26 \\
27 \\
28 \\
29\end{array}$ & $\begin{array}{l}1.00 \\
1.06 \\
1.31 \\
1.25\end{array}$ & $\begin{array}{l}.74 \\
.79 \\
.93 \\
.87\end{array}$ & $\begin{array}{l}- \\
.06 \\
.06 \\
.06\end{array}$ & $\begin{array}{c}- \\
16.57 \\
19.37 \\
18.35\end{array}$ & $\begin{array}{l}<.001 \\
<.001 \\
<.001 \\
<.001\end{array}$ & .93 & .76 \\
\hline F5 & $\begin{array}{l}30 \\
31 \\
32 \\
33\end{array}$ & $\begin{array}{l}1.00 \\
0.87 \\
0.86 \\
0.99\end{array}$ & $\begin{array}{l}.68 \\
.88 \\
.89 \\
.74\end{array}$ & $\begin{array}{l}- \\
.05 \\
.05 \\
.07\end{array}$ & $\begin{array}{c}- \\
15.99 \\
16.07 \\
13.90\end{array}$ & $\begin{array}{l}<.001 \\
<.001 \\
<.001 \\
<.001\end{array}$ & .95 & .83 \\
\hline F6 & $\begin{array}{l}34 \\
35 \\
36\end{array}$ & $\begin{array}{l}1.00 \\
1.11 \\
1.15\end{array}$ & $\begin{array}{l}.75 \\
.86 \\
.81\end{array}$ & $\begin{array}{c}- \\
.06 \\
.07\end{array}$ & $\begin{array}{c}- \\
17.36 \\
16.27\end{array}$ & $\begin{array}{l}<.001 \\
<.001 \\
<.001\end{array}$ & .88 & .71 \\
\hline F7 & $\begin{array}{l}37 \\
38 \\
39 \\
40 \\
41 \\
42 \\
43 \\
44\end{array}$ & $\begin{array}{l}1.00 \\
0.83 \\
0.97 \\
0.94 \\
0.81 \\
0.80 \\
0.78 \\
0.91\end{array}$ & $\begin{array}{l}.75 \\
.86 \\
.81 \\
.84 \\
.85 \\
.86 \\
.86 \\
.84\end{array}$ & $\begin{array}{l}- \\
.03 \\
.04 \\
.04 \\
.03 \\
.03 \\
.04 \\
.05\end{array}$ & $\begin{array}{c}- \\
22.39 \\
23.14 \\
23.10 \\
22.19 \\
23.12 \\
16.09 \\
18.20\end{array}$ & $\begin{array}{l}<.001 \\
<.001 \\
<.001 \\
<.001 \\
<.001 \\
<.001 \\
<.001 \\
<.001\end{array}$ & .98 & .82 \\
\hline F8 & $\begin{array}{l}45 \\
46 \\
47 \\
48 \\
49 \\
50 \\
51 \\
52\end{array}$ & $\begin{array}{l}1.00 \\
0.99 \\
1.06 \\
1.17 \\
0.89 \\
1.03 \\
0.82 \\
1.13\end{array}$ & $\begin{array}{l}.86 \\
.68 \\
.74 \\
.70 \\
.74 \\
.80 \\
.87 \\
.88\end{array}$ & $\begin{array}{l}- \\
.06 \\
.06 \\
.06 \\
.05 \\
.06 \\
.04 \\
.06\end{array}$ & $\begin{array}{c}- \\
14.68 \\
15.91 \\
17.28 \\
15.91 \\
16.71 \\
19.74 \\
17.39\end{array}$ & $\begin{array}{l}<.001 \\
<.001 \\
<.001 \\
<.001 \\
<.001 \\
<.001 \\
<.001 \\
<.001\end{array}$ & .98 & .85 \\
\hline
\end{tabular}

NSPDS=Nursing student perceptions of dishonesty scale; $\mathrm{SE}=$ Standard error; $\mathrm{CR}=$ Construct reliability; AVE=Average variance extracted; F1=Cheating; F2=Assistance; F3=Cutting corners; F4=Not my problem; F5=Sabotage; F6=Test file; F7=Perjury; F8=Noncompliance; Model fit: Normed Chi-square=2.96, SRMR=.05, TLI=.90, CFI=.91, RMSEA=.06 (low=.05, high=.07), Reference level of fitness index: Normed Chi-square $<3.0$, SRMR $<1.0$, TLI $\geq .90$, CFI $\geq 90$, RMSEA $\leq 1.0$, Factor loading $<.50$, CR $>.70$, AVE $>.50$. 
coefficient among subscales was at a minimum of $.30(p<$ $.001)$ to a maximum of $.67(p<.001)$. Furthermore, the correlation coefficient between factors was less than .80 and the AVE of latent variables was greater than the square of the correlation coefficients of the latent variables. We confirmed the discriminant validity of the factor (Tables 2, 3).

\section{Criterion-related Validity}

There was a negative correlation between student nurses' ethical value measuring tool and the Korean version of the NSPDS $(\mathrm{r}=-.56, p<.001)$ (Table 3$)$.

\section{Reliability Analysis}

The internal consistency reliability of the Korean version of the NSPDS test showed Cronbach's $\alpha$.80 .95 in the subscales. Test-retest reliability was conducted to confirm the stability of the measurement for each factor. The stability of measurement confirmed that the correlation coefficient showed significant positive correlations between .68 and .76 in the subscales (Table 4 ).

\section{Item Analysis}

The mean item was 1.14 2.74, while the standard deviation was $0.42 \sim 1.05$, which concluded that there was no item with extreme value. The normal distribution was confirmed with a skewness $-0.67 \sim 0.93$ and kurtosis $-0.90 \sim 0.85$ (Table 4).

\section{DISCUSSION}

This study was conducted to confirm the validity of the Korean version of the NSPDS, which is the main focus of the discussion. First, this study followed the tool translation and application guidelines suggested by the WHO in order to secure content validity for the Korean version of the NSPDS. Nursing professors from the nursing department and experts reviewed item relevance, adequacy, and representativeness in the subscale, and revised some terminologies not applicable to Korea, as well as awkward expressions and phrases. Cognitive validity assessment was secured through student nurses, who were evaluated using the actual tool.

Table 3. Convergent and Discriminant Validity of Korean NSPDS among Sub-scales

\begin{tabular}{|c|c|c|c|c|c|c|c|c|c|}
\hline \multirow[t]{2}{*}{ Variables } & $\begin{array}{c}\text { Total } \\
\text { NSPDS }\end{array}$ & $\mathrm{F} 1$ & F2 & F3 & $\mathrm{F} 4$ & F5 & F6 & F7 & F8 \\
\hline & $r(p)$ & $r(p)$ & $r(p)$ & $r(p)$ & $r(p)$ & $r(p)$ & $r(p)$ & $\mathrm{r}(p)$ & $r(p)$ \\
\hline $\mathrm{F} 1$ & $\begin{array}{c}.71 \\
(<.001)\end{array}$ & .81 & & & & & & & \\
\hline F2 & $\begin{array}{c}.63 \\
(<.001)\end{array}$ & $\begin{array}{c}.39 \\
(<.001)\end{array}$ & .53 & & & & & & \\
\hline F3 & $\begin{array}{c}.70 \\
(<.001)\end{array}$ & $\begin{array}{c}.43 \\
(<.001)\end{array}$ & $\begin{array}{c}.50 \\
(<.001)\end{array}$ & .53 & & & & & \\
\hline $\mathrm{F} 4$ & $\begin{array}{c}.63 \\
(<.001)\end{array}$ & $\begin{array}{c}.48 \\
(<.001)\end{array}$ & $\begin{array}{c}.48 \\
(<.001)\end{array}$ & $\begin{array}{c}.38 \\
(<.001)\end{array}$ & .76 & & & & \\
\hline F5 & $\begin{array}{c}.64 \\
(<.001)\end{array}$ & $\begin{array}{c}.60 \\
(<.001)\end{array}$ & $\begin{array}{c}.37 \\
(<.001)\end{array}$ & $\begin{array}{c}.49 \\
(<.001)\end{array}$ & $.32(<.001)$ & .83 & & & \\
\hline F6 & $\begin{array}{c}.79 \\
(<.001)\end{array}$ & $\begin{array}{c}.52 \\
(<.001)\end{array}$ & $\begin{array}{c}.47 \\
(<.001)\end{array}$ & $\begin{array}{c}.52 \\
(<.001)\end{array}$ & $.37(<.001)$ & $\begin{array}{c}.44 \\
(<.001)\end{array}$ & .71 & & \\
\hline F7 & $\begin{array}{c}.71 \\
(<.001)\end{array}$ & $\begin{array}{c}.54 \\
(<.001)\end{array}$ & $\begin{array}{c}.43 \\
(<.001)\end{array}$ & $\begin{array}{c}.43 \\
(<.001)\end{array}$ & $.30(<.001)$ & $\begin{array}{c}.53 \\
(<.001)\end{array}$ & $.46(>.001)$ & .82 & \\
\hline F8 & $\begin{array}{c}.68 \\
(<.001)\end{array}$ & $\begin{array}{c}.51 \\
(<.001)\end{array}$ & $\begin{array}{c}.43 \\
(<.001)\end{array}$ & $\begin{array}{c}.41 \\
(<.001)\end{array}$ & $.43(<.001)$ & $\begin{array}{c}.50 \\
(<.001)\end{array}$ & $.42(<.001)$ & $\begin{array}{c}.67 \\
(<.001)\end{array}$ & .85 \\
\hline $\begin{array}{c}\text { Ethical } \\
\text { values }\end{array}$ & $\begin{array}{c}-.56 \\
(<.001)\end{array}$ & $\begin{array}{c}-.58 \\
(<.001)\end{array}$ & $\begin{array}{c}-.57 \\
(<.001)\end{array}$ & $\begin{array}{c}-.59 \\
(<.001)\end{array}$ & $-.53(<.001)$ & $\begin{array}{c}-.56 \\
(<.001)\end{array}$ & $\begin{array}{c}-.60 \\
(<.001)\end{array}$ & $\begin{array}{c}-.57 \\
(<.001)\end{array}$ & $\begin{array}{c}-.49 \\
(<.001)\end{array}$ \\
\hline
\end{tabular}

The oblique shaded section: AVE; The non-shaded section: correlation; NSPDS=Student nurses' perceptions of dishonesty scale; SE=Standard error; $\mathrm{CR}=$ Construct reliability; $\mathrm{AVE}=$ Average variance extracted; $\mathrm{F} 1=$ Cheating; $\mathrm{F} 2=$ Assistance; $\mathrm{F} 3=\mathrm{Cutting}$ corners; F4=Not my problem; F5=Sabotage; F6=Test file; F7=Perjury; F8=Noncompliance. 
Table 4. Item Analysis and Reliability of NSPDS

\begin{tabular}{|c|c|c|c|c|c|c|c|c|c|}
\hline Factors & Item no & $\mathrm{M}$ & SD & SE & Skewness & Kurtosis & $\begin{array}{l}\alpha \text { if item } \\
\text { deleted }\end{array}$ & $\alpha$ & $\begin{array}{c}\text { Test-retest (r) } \\
\text { (2 weeks) }\end{array}$ \\
\hline F1 & $\begin{array}{c}1 \\
2 \\
3 \\
4 \\
5 \\
6 \\
7 \\
8 \\
9 \\
10 \\
11 \\
12 \\
13\end{array}$ & $\begin{array}{l}1.24 \\
1.21 \\
1.33 \\
1.15 \\
1.27 \\
1.14 \\
1.36 \\
1.21 \\
1.60 \\
1.35 \\
1.29 \\
1.35 \\
1.17\end{array}$ & $\begin{array}{l}0.55 \\
0.52 \\
0.69 \\
0.42 \\
0.62 \\
0.42 \\
0.74 \\
0.55 \\
0.94 \\
0.70 \\
0.65 \\
0.73 \\
0.44\end{array}$ & $\begin{array}{l}.03 \\
.02 \\
.03 \\
.02 \\
.03 \\
.02 \\
.04 \\
.03 \\
.04 \\
.03 \\
.03 \\
.03 \\
.02\end{array}$ & $\begin{array}{l}0.50 \\
0.90 \\
0.13 \\
0.28 \\
0.32 \\
0.49 \\
0.89 \\
0.73 \\
0.31 \\
0.88 \\
0.18 \\
0.09 \\
0.84\end{array}$ & $\begin{array}{l}0.18 \\
0.33 \\
0.84 \\
0.85 \\
0.43 \\
0.15 \\
0.40 \\
0.29 \\
0.43 \\
0.55 \\
0.84 \\
0.48 \\
0.62\end{array}$ & $\begin{array}{l}.94 \\
.94 \\
.94 \\
.94 \\
.94 \\
.94 \\
.94 \\
.94 \\
.95 \\
.94 \\
.94 \\
.94 \\
.94\end{array}$ & .95 & $.70^{*}$ \\
\hline F2 & $\begin{array}{l}14 \\
15 \\
16 \\
17 \\
18\end{array}$ & $\begin{array}{l}1.76 \\
2.40 \\
2.19 \\
2.74 \\
2.34\end{array}$ & $\begin{array}{l}0.96 \\
1.03 \\
1.00 \\
0.95 \\
1.02\end{array}$ & $\begin{array}{l}.05 \\
.05 \\
.05 \\
.05 \\
.05\end{array}$ & $\begin{array}{c}0.80 \\
-0.19 \\
0.05 \\
-0.67 \\
-0.09\end{array}$ & $\begin{array}{l}-0.81 \\
-0.20 \\
-0.35 \\
-0.46 \\
-0.26\end{array}$ & $\begin{array}{l}.83 \\
.81 \\
.78 \\
.81 \\
.79\end{array}$ & .83 & $.68^{*}$ \\
\hline F3 & $\begin{array}{l}19 \\
20 \\
21 \\
22 \\
23 \\
24 \\
25\end{array}$ & $\begin{array}{l}2.00 \\
2.21 \\
2.56 \\
2.42 \\
2.58 \\
2.30 \\
2.06\end{array}$ & $\begin{array}{l}1.00 \\
1.04 \\
0.99 \\
0.98 \\
0.99 \\
0.96 \\
1.04\end{array}$ & $\begin{array}{l}.05 \\
.05 \\
.05 \\
.05 \\
.05 \\
.05 \\
.05\end{array}$ & $\begin{array}{c}0.43 \\
0.14 \\
-0.41 \\
-0.14 \\
-0.14 \\
-0.43 \\
0.12\end{array}$ & $\begin{array}{l}-0.07 \\
-0.25 \\
-0.90 \\
-0.01 \\
-0.03 \\
-0.83 \\
-0.17\end{array}$ & $\begin{array}{l}.87 \\
.87 \\
.87 \\
.86 \\
.86 \\
.86 \\
.86\end{array}$ & .87 & $.76^{*}$ \\
\hline F4 & $\begin{array}{l}26 \\
27 \\
28 \\
29\end{array}$ & $\begin{array}{l}1.87 \\
1.83 \\
1.33 \\
1.20\end{array}$ & $\begin{array}{l}0.91 \\
0.90 \\
0.86 \\
0.86\end{array}$ & $\begin{array}{l}.04 \\
.04 \\
.04 \\
.04\end{array}$ & $\begin{array}{l}0.19 \\
0.18 \\
0.45 \\
0.57\end{array}$ & $\begin{array}{l}-0.17 \\
-0.15 \\
-0.00 \\
-0.84\end{array}$ & $\begin{array}{l}.88 \\
.85 \\
.87 \\
.89\end{array}$ & .90 & $.73^{*}$ \\
\hline F5 & $\begin{array}{l}30 \\
31 \\
32 \\
33\end{array}$ & $\begin{array}{l}1.18 \\
1.39 \\
1.97 \\
1.67\end{array}$ & $\begin{array}{l}0.63 \\
0.46 \\
0.46 \\
0.69\end{array}$ & $\begin{array}{l}.03 \\
.02 \\
.02 \\
.03\end{array}$ & $\begin{array}{l}0.93 \\
0.27 \\
0.68 \\
0.81\end{array}$ & $\begin{array}{l}0.20 \\
0.55 \\
0.41 \\
0.65\end{array}$ & $\begin{array}{l}.81 \\
.79 \\
.79 \\
.83\end{array}$ & .83 & $.73^{*}$ \\
\hline F6 & $\begin{array}{l}34 \\
35 \\
36\end{array}$ & $\begin{array}{l}1.82 \\
1.54 \\
1.39\end{array}$ & $\begin{array}{l}1.05 \\
0.92 \\
0.99\end{array}$ & $\begin{array}{l}.05 \\
.04 \\
.05\end{array}$ & $\begin{array}{l}0.55 \\
0.10 \\
0.74\end{array}$ & $\begin{array}{l}-0.12 \\
-0.01 \\
-0.86\end{array}$ & $\begin{array}{l}.78 \\
.74 \\
.80\end{array}$ & .80 & $.72^{*}$ \\
\hline F7 & $\begin{array}{l}37 \\
38 \\
39 \\
40 \\
41 \\
42 \\
43 \\
44\end{array}$ & $\begin{array}{l}1.45 \\
1.43 \\
1.36 \\
1.34 \\
1.44 \\
1.48 \\
1.36 \\
1.39\end{array}$ & $\begin{array}{l}0.72 \\
0.59 \\
0.68 \\
0.66 \\
0.59 \\
0.56 \\
0.69 \\
0.74\end{array}$ & $\begin{array}{l}.03 \\
.03 \\
.03 \\
.03 \\
.03 \\
.03 \\
.03 \\
.03\end{array}$ & $\begin{array}{l}0.15 \\
0.41 \\
0.39 \\
0.31 \\
0.44 \\
0.48 \\
0.43 \\
0.42\end{array}$ & $\begin{array}{l}0.58 \\
0.61 \\
0.28 \\
0.67 \\
0.40 \\
0.67 \\
0.23 \\
0.19\end{array}$ & $\begin{array}{l}.94 \\
.94 \\
.93 \\
.93 \\
.94 \\
.94 \\
.94 \\
.94\end{array}$ & .94 & $.72^{*}$ \\
\hline F8 & $\begin{array}{l}45 \\
46 \\
47 \\
48 \\
49 \\
50 \\
51 \\
52\end{array}$ & $\begin{array}{l}1.31 \\
1.31 \\
1.32 \\
1.23 \\
1.28 \\
1.28 \\
1.39 \\
1.48\end{array}$ & $\begin{array}{l}0.63 \\
0.62 \\
0.58 \\
0.58 \\
0.59 \\
0.49 \\
0.53 \\
0.56\end{array}$ & $\begin{array}{l}.03 \\
.03 \\
.03 \\
.03 \\
.03 \\
.03 \\
.03 \\
.03\end{array}$ & $\begin{array}{l}0.82 \\
0.35 \\
0.77 \\
0.85 \\
0.80 \\
0.19 \\
0.78 \\
0.86\end{array}$ & $\begin{array}{l}0.16 \\
0.70 \\
0.39 \\
0.03 \\
0.80 \\
0.84 \\
0.25 \\
0.42\end{array}$ & $\begin{array}{l}.92 \\
.92 \\
.92 \\
.91 \\
.91 \\
.92 \\
.91 \\
.91\end{array}$ & .92 & $.73^{*}$ \\
\hline
\end{tabular}

NSPDS=Student nurses perceptions of dishonesty scale; $\mathrm{M}=\mathrm{Mean}, \mathrm{SD}=\mathrm{Standard}$ deviation; $\mathrm{SE}=\mathrm{Standard}$ error; ITC=Item-total correlation ; F1=Cheating; F2=Assistance; F3=Cutting corners; F4=Not my problem; F5=Sabotage; F6=Test file; F7=Perjury; F8=Noncompliance; ${ }^{*} p<.05$. 
Furthermore, the content validity of the NSPDS was confirmed using confirmatory factor analysis, exploratory factor analysis, and criterion-related validity analysis. Since confirmatory factor analysis is more appropriate for the application of the tool with confirmed validity after translating into another language [27], in this study conducted a confirmatory factor analysis was conducted to determine which factors developed in the U.S. were still suitable in Korea. However, new model estimation was required as the fit index of the model was low, and it was also based on the suggestion of establishing a causal relationship between one observation variable and multiple factors. Therefore, all items related to stealing in clinical setting subscales were deleted based on exploratory factor analysis of the total items, and the Korean version of the NSPDS was completed with 8 subscales. Stealing is a crime in Korea, so students may perceive stealing as an unethical behavior. However, the environment or structure in Korea does not allow nursing students to use food or medicine for their own purpose. Therefore, it is considered that this item could not be linked to evaluating the perception of dishonest behaviors that nursing students can experience. In addition, among the deleted items, some items such as "document things unreported as reported," "document the general status of the patients by making it up," "provide inappropriate information to patients," and "sign confirmation for medication loss without checking the contents with one's own eyes," are possible only with autonomy for student nurses during clinical practice. However, the clinical practice of student nurses in Korea is only conducted under the direct supervision of the preceptor. Therefore, signing medical charts or incidents related to patient information cannot be performed independently. Thus, the Korean version of the NSPDS has a similar structure to the subscales and detailed items to the original tool, except for the deleted items due to cultural differences between the U.S. and Korea. Furthermore, convergent and discriminant validity were tested for the validity of component factors determined from the confirmatory factor analysis, and the results confirmed that the validity of the Korean version of the NSPDS. In the case of the Korean version compared to the original version of the NSPDS, cheating, assistance, cutting corners, not my problem, sabotage, test file, perjury, and noncompliance are considered to be academic dishonesty that is common to student nurses. Therefore, we suggest that nurse educators need to provide and develop educational programs that include these components for student nurses.

In order to test criterion-related validity, this study showed that the Korean version of the NSPDS and the eth- ical value measuring tool of Kim [21] yielded differences while measuring the same concepts with a correlation coefficient of $r=-.56$. Based on previous research that human dishonesty in the organization is related to ethical value judgment [28], this study hypothesized that higher academic dishonesty among student nurses will show low ethical value and tested correlation. Further studies on predicting validity to assess whether academic dishonesty of student nurses is related to the point when they become clinical nurses are recommended.

In this study, the internal consistency reliability of the Korean version of the NSPDS was Cronbach's $\alpha$.80 .95, which is relatively high. Internal consistency reliability was confirmed with a value of $>.70$ [29]. This is similar to the results obtained in a study in the U.S. [18]. The Korean version of the NSPDS can be considered a tool with high internal consistency reliability. The test-retest reliability in the study showed a Pearson correlation coefficient of $r=$ .68 .76. In the case of test-retest, if the correlation coefficient is .70 or above, it is judged to be highly reliable [30]. It is believed that 2 weeks is sufficient to evaluate the reliability of the Korean version of the NSPDS. Finally, as a result of conducting item analysis on the final items, students found that the items in "assistance" and "cutting corners" were relatively higher than those in other subscales. It was difficult to compare the results with the original NSPDS because it did not describe the results of the item analysis at the time of the development of NSPDS, but it seems that Korean students are sensitive to the "assistance" and the "cutting corners" items of academic dishonesty. The limitation of this study is that students in some parts of Korea were excluded, and it is also necessary to confirm the degree of students' perceptions of academic dishonesty may vary for students at universities established by religious groups.

\section{CONCLUSION}

This study was conducted to confirm the validity and reliability of the Korean version of the NSPDS, to evaluate student nurses' perception of dishonest behaviors and to provide baseline data for nursing education in nursing trated to work ethics. The final Korean version of the NSPDS consisted of 8 factors and 52 items. Further studies on the degree of academic dishonesty among Korean student nurses using the Korean version of the NSPDS, factors affecting their dishonesty, and associations between dishonesty experienced in school and clinic environments are recommended. In addition, it is necessary to study for verification of the Korean version with developer and to 
further verify the reliability of the NSPDS for student in various school environments.

\section{REFERENCES}

1. Bretag T, Mahmud S, Wallace M, Walker R, James C, Green M, et al. Core elements of exemplary academic integrity policy in Australian higher education. International Journal for Educational Integrity. 2011;7(2):3-12.

https://doi.org/10.21913/IJEI.v7i2.759

2. McCabe DL. The influence of situational ethics on cheating among college students. Sociological Inquiry. 1992;62(3):365-374. https://doi.org/10.1111/j.1475-682X.1992.tb00287.x

3. Jeong GS. The differences of nurses' perception of the code of ethics, degree of application of nursing ethics and biomedical ethical consciousness according to nursing students' clinical practice experience, ethical values and biomedical ethics education. The Journal of Korean Academic Society of Nursing Education. 2018;24(3):300-310.

https://doi.org/10.5977/jkasne.2018.24.3.300

4. Pence PL. Plagiarism: using a collaborative approach in an online allied health professions course. Nurse Educator. 2012;37 (1):12-16. https:// doi.org/10.1097/NNE.0b013e3182383701

5. LaDuke RD. Academic dishonesty today, unethical practices tomorrow? Journal of Professional Nursing. 2013;29(6):402-406. https://doi.org/10.1016/j.profnurs.2012.10.009

6. Holloway I, Galvin K. Qualitative research in nursing and healthcare. 4th ed. Wiley Blackwell: John Wiley \& Sons; 2016. p. 161-162.

7. Arhin AO. A pilot study of nursing student's perceptions of academic dishonesty: a generation $\mathrm{Y}$ perspective. The ABNF Journal. 2009;20(1):17-21.

8. Grimes PW. Dishonesty in academics and business: a crosscultural evaluation of student attitudes. Journal of Business Ethics. 2004;49(3):273-290.

https://doi.org/10.1023/B:BUSI.0000017969.29461.30

9. Krueger L. Academic dishonesty among nursing students. Journal of Nursing Education. 2014;53(2):77-87. https://doi.org/10.3928/01484834-20140122-06

10. Duska R, Whelan M. Moral development: a guide to Piaget and Kohlberg. New York: Paulist Press; 1975. p. 72.

11. Baxter PE, Boblin SL. The moral development of baccalaureate nursing students: understanding unethical behavior in classroom and clinical settings. Journal of Nursing Education. 2007; 46(1):20-27. https://doi.org/10.3928/01484834-20070101-05

12. Carpenter DD, Harding TS, Finelli CJ, Passow HJ. Does academic dishonesty relate to unethical behavior in professional practice? an exploratory study. Science and Engineering Ethics. 2004;10(2):311-324. https://doi.org/10.1007/s11948-004-0027-3
13. Erdil F, Korkmaz F. Ethical problems observed by student nurses. Nursing Ethics. 2009;16(5):589-598.

https://doi.org/10.1177/0969733009106651

14. Park HO, Lee I, Lee M. The survey on the awareness towards academic misconduct required in the convergence era: focusing on nursing students. Journal of Digital Convergence. 2018; 16(5):277-287. https://doi.org/10.14400/JDC.2018.16.5.277

15. McClung EL, Schneider JK. The development and testing of the nursing student perceptions of dishonesty scale. Nurse Education Today. 2018;61:28-35.

https://doi.org/10.1016/j.nedt.2017.11.002

16. McCabe DL. Academic dishonesty in nursing schools: an empirical investigation. Journal of Nursing Education. 2009;48 (11):614-623. https://doi.org/10.3928/01484834-20090716-07

17. Hinkin TR. A brief tutorial on the development of measures for use in survey questionnaires. Organizational Research Methods. 1998;1(1):104-121. https://doi.org/10.1177/109442819800100106

18. Anderson JC, Gerbing DW. Structural equation modeling in practice: a review and recommended two-step approach. Psychological Bulletin. 1998;103(3):411-423.

19. Kim SH, Yoo SY, Kim YY. Validity and reliability of the Korean version scale of the Clinical Learning Environment, Supervision and Nurse Teacher Evaluation Scale (CLES+T). Journal of Korean Academy of Nursing. 2018;48(1):70-84. https://doi.org/10.4040/jkan.2018.48.1.70

20. Jong HJ, Moon HJ. A study of ethical sense of value and discord of the clinical nurse. Journal of Korean Academy of Nursing Administration. 1995;1(2):349-371.

21. Kim YS. A study on the comparison of consciousness on ethics between clinical nurses and student nurses [Master's Thesis]. Jinju: Gyeongsang National University of Korea; 2004. p. 66.

22. World Health Organization. World Health Organization. World health statistics 2016: monitoring health for the SDGs sustainable development goals. Geneva: WHO press; 2016. p. 6.

23. Kim GS. Amos 18.0 analysis structural equation modeling. Seoul: Hannarae; 2010. p. 1-663.

24. Polit DF, Beck CT, Owen SV. Is the CVI an acceptable indicator of content validity? appraisal and recommendations. Research in Nursing and Health. 2007;30(4):459-467. https://doi.org/10.1002/nur.20199

25. Tabachnick BG, Fidell LS. Using multivariate statistics. 5th ed. Boston, MA: Pearson Education; 2007. p. 22.

26. Hair JF, Black WC, Babin BJ, Anderson RE. Multivariate data analysis: a global perspective. 7th ed. Upper Saddle River NJ: Pearson Prentice Hall; 2010. p. 109-136.

27. Geldhof GJ, Preacher KJ, Zyphur MJ. Reliability estimation in a multilevel confirmatory factor analysis framework. Psychological Methods. 2014;19(1):72-91. https://doi.org/10.1037/a0032138 
28. Kindsiko E. (Dis) honesty in organizations: ethical perspectives. (Dis)Honesty in Management (Advanced Series in Manage ment). 2013;10:19-35.

https://doi.org/10.1108/S1877-6361(2013)0000010006

29. DeVon HA, Block ME, Moyle-Wright P, Ernst DM, Hayden SJ, Lazzara DJ, et al. A psychometric toolbox for testing validity and reliability. Journal of Nursing Scholarship. 2007;39(2): 155-164. https://doi.org/10.1111/j.1547-5069.2007.00161.x

30. Leppink J, Pérez-Fuster P. We need more replication researcha case for test-retest reliability. Perspectives on Medical Education, 2017;6(3):158-164.

https://doi.org/10.1007/s40037-017-0347-z 


\section{Supplement 1. 최종문항}

\begin{tabular}{|c|c|}
\hline 번호 & *나는 (문항 번호의 내용) 것이 학문적 부정직 행동이라고 생각한다. \\
\hline & 학교영역 (속임수) \\
\hline 1 & 시험 중 문자 메세지로 답을 받기도 한다. \\
\hline 2 & 시험 중 문자 메세지로 답을 보내기도 한다. \\
\hline 3 & 시험 중 커닝 페이퍼를 사용하기도 한다. \\
\hline 4 & 대리로 시험을 보기도 한다. \\
\hline 5 & 시험 중 다른 사람의 시험 답안지를 몰래 보기도 한다. \\
\hline 6 & 대리시험을 부탁하기도 한다. \\
\hline 7 & 다른 사람의 결과물을 자기 과제로 제출하기도 한다. \\
\hline 8 & 시험 중 수신호나 소리 등으로 답을 공유하기도 한다. \\
\hline 9 & 다른 사람으로부터 과제를 구매하기도 한다. \\
\hline 10 & 다른 사람의 과제를 대신 해 주기도 한다. \\
\hline 11 & 시험 중 다른 사람에게 답을 보여주기도 한다. \\
\hline 12 & 다른 사람에게 과제를 팔기도 한다. \\
\hline \multirow[t]{2}{*}{13} & 꾀병으로 시험을 연기하기도 한다. \\
\hline & 학교영역 (조력) \\
\hline 14 & 과제검토 (맞춤법, 띄어쓰기 등)를 부탁하기도 한다. \\
\hline 15 & 과제에 대한 설명을 부탁하기도 한다. \\
\hline 16 & 과제를 할 때 문체와 문단 구성 등을 도와주기도 한다. \\
\hline 17 & 과제에 대한 설명을 해 주기도 한다. \\
\hline \multirow[t]{2}{*}{18} & 동료의 과제를 검토 (맞춤법, 띄어쓰기 등)해 주기도 한다. \\
\hline & 학교영역 (대충하기) \\
\hline 19 & 독후감 과제를 책 대신 영화를 보고 제출하기도 한다, \\
\hline 20 & 영어로 읽어야 하는 과제를 한국어 버전을 구해 읽기도 한다. \\
\hline 21 & 책 전문 (全文) 대신 요약본을 읽기도 한다. \\
\hline 22 & 글자 크기를 크게 해 결과물을 많아 보이게 만들기도 한다. \\
\hline 23 & 여백을 넓게 해 결과물을 많아 보이게 만들기도 한다. \\
\hline 24 & 개인 과제를 동료와 토론하며 함께 풀기도 한다. \\
\hline \multirow[t]{2}{*}{25} & 개인 과제를 동료와 분담하여 각자 푼 후 취합하여 제출하기도 한다. \\
\hline & 학교영역 (내 문제가 아님) \\
\hline 26 & 시험 중 목격한 부정행위를 보고하지 않기도 한다. \\
\hline 27 & 실습 중 목격한 부정행위를 보고하지 않기도 한다. \\
\hline 28 & 표절을 알고도 보고하지 않기도 한다. \\
\hline \multirow[t]{2}{*}{29} & 이전 시험문제가 유포된 것을 보고하지 않기도 한다. \\
\hline & 학교영역 (방해) \\
\hline 30 & 동료의 실험/실습을 방해하기도 한다. \\
\hline 31 & 도서관 자료를 파손하기도 한다. \\
\hline 32 & 자료를 일부러 파손시켜 동료의 과제 제출을 방해하기도 한다. \\
\hline \multirow[t]{2}{*}{33} & 팀 과제 중 자신이 맡은 부분을 소홀히 하기도 한다. \\
\hline & 학교영역 (평가파일) \\
\hline 34 & 시험문제 (족보)를 가지고 공부하기도 한다. \\
\hline 35 & 시험문제 (족보)를 관리하기도 한다. \\
\hline \multirow[t]{2}{*}{36} & 문제은행을 이용해 공부하기도 한다. \\
\hline & 임상영역 (위증) \\
\hline 37 & 환자의 ROM을 확인하지 않고 ROM을 기록하기도 한다. \\
\hline 38 & 환자 목욕을 확인하지 않고 완료했다고 간호사에게 보고하기도 한다. \\
\hline 39 & 환자의 통증을 사정하지 않고 통증 점수를 기록하기도 한다. \\
\hline 40 & 환자 체위를 변경하지 않고 체위변경 간호를 수행한 것으로 기록하기도 한다. \\
\hline 41 & 폐음 청진을 하지 않고 정상 폐음으로 기록하기도 한다. \\
\hline 42 & 환자에게 물어보지 않고 식사를 거부한다고 보고하기도 한다. \\
\hline 43 & 환자의 활력징후를 측정하지 않고 기록하기도 한다. \\
\hline 44 & 환자 사정을 하지 않고 간호사가 작성한 것을 그대로 기록하기도 한다. \\
\hline \multirow[t]{2}{*}{45} & 환자 라운딩을 하지 않고 라운딩 내용을 기록하기도 한다. \\
\hline & 임상영역 (불이행) \\
\hline 46 & 약물에 공동 확인 서명할 간호사를 찾지 못하기도 한다. \\
\hline 47 & 환자에게 바닥에 떨어뜨린 약물을 그대로 투약하기도 한다. \\
\hline 48 & 환자의 낙상을 보고하지 않기도 한다. \\
\hline 49 & 투약오류를 발견하고도 보고 하지 않기도 한다. \\
\hline 50 & 휴게실 냉장고에 있는 타인의 음식을 먹기도 한다. \\
\hline 51 & 의사의 처방대로 간호하지 않기도 한다. \\
\hline 52 & 투약 실수 후 보고하지 않기도 한다. \\
\hline
\end{tabular}

